\title{
ANALISIS SOAL UJIAN NASIONAL BAHASA INDONESIA PADA TINGKAT SMP TAHUN AJARAN 2018/2019 DALAM PERSPEKTIF KEBIJAKAN PENDIDIKAN
}

\author{
Eva Kurniawati \\ Program Pascasarjana Universitas Negeri Yogyakarta \\ Corresponding Email: evakurniawati7474@gmail.com
}

Received: 13th of July 2020, Accepted: $19^{\text {th }}$ of October 2020, Published: $12^{\text {th }}$ of December 2020

\begin{abstract}
Abstrak
Penelitian ini bertujuan untuk mengetahui dan menganalisis kesesuaian soal Ujian Nasional (UN) Bahasa Indonesia tingkat SMP pada tahun ajaran 2018/2019 berdasarkan kebijakan pendidikan yang berlaku. Penelitian yang dilaksanakan menggunakan metode deskriptif kualitatif. Pada penelitian ini, yang menjadi instrumen penelitian adalah human instrument atau peneliti itu sendiri. Peneliti melakukan teknik baca dan catat dengan berpedoman pada kisi-kisi analisis butir soal Bahasa Indonesia berdasarkan Surat Keputusan BSNP Nomor 0296/SKEP/BSNP/XI/2018 tentang Kisi-Kisi Ujian UN untuk Jenjang Dasar dan Menengah. Data dikumpulkan dengan cara dokumentasi. Uji keabsahan data dalam penelitian ini menggunakan uji kredibilitas. Hasil yang ditemukan dalam penelitian ini adalah terdapat lima macam lingkup materi pada soal Ujian Nasional (UN) Bahasa Indonesia tingkat SMP pada tahun ajaran 2018/2019. Berdasarkan hal tersebut, dapat diketahui bahwa soal Ujian Nasional (UN) Bahasa Indonesia tingkat SMP pada tahun ajaran 2018/2019 memiliki kesesuaian dengan Surat Keputusan BSNP Nomor 0296/SKEP/BSNP/XI/2018 pada pasal 1, 2, 3, dan 4.
\end{abstract}

Kata Kunci: ujian nasional, bahasa indonesia, kebijakan pendidikan

\begin{abstract}
This study aims to determine and analyze the suitability of the Indonesian National Examination (UN) questions for SMP level in the 2018/2019 academic year based on applicable educational policies. This research was conducted using a qualitative descriptive method. In this research, the research instrument is the human instrument or the researcher himself. Researchers carried out reading and note-taking techniques guided by the grid analysis of Indonesian language questions based on the Decree of BSNP Number 0296 SKEP/BSNP/XI/2018 concerning National Exam Grids for Elementary and Middle Levels. Data collected by means of documentation. Test the validity of the data in this study using the credibility test. The results found in this study were that there were five types of material scopes in the Indonesian National Examination (UN) questions for the SMP level in the 2018/2019 academic year. Based on this, it can be seen that the Indonesian National Examination (UN) questions for SMP level in the 2018/2019 academic year are in conformity with BSNP Decree Number 0296 SKEP/BSNP/XI/2018 in articles 1, 2, 3, and 4.
\end{abstract}

Keywords: national examination, indonesian language, education policy.

Copyright (๑) 2020 Eva Kurniawati

\section{PENDAHULUAN}

Pada dasarnya, pembelajaran dapat diartikan sebagai suatu proses perubahan peserta didik dari yang tidak tahu menjadi tahu, dari yang tidak dapat menjadi dapat, dan dapat diukur pula hasilnya. Di sisi lain, pembelajaran juga dianggap sebagai bantuan yang diberikan 
pendidik agar dapat terjadi proses perolehan ilmu dan pengetahuan, penguasaan kemahiran dan tabiat, serta pembentukan sikap dan kepercayaan pada peserta didik.

Dalam proses pembelajaran, tentu memiliki komponen-komponen yang saling berkaitan. Komponen-komponen pembelajaran tersebut diantaranya adalah tujuan, materi pelajaran, metode, media, dan evaluasi (Sanjaya, 2013:58). Untuk mengetahui keberhasilan pembelajaran, maka dapat dilakukan penilaian sebagai cerminan dalam menggambarkan kemampuan atau kompetensi peserta didik yang diperlukan oleh pendidik, peserta didik, dan orang tua untuk mengetahui keberhasilan proses pembelajaran. Oleh karena itu, dapat diketahui bahwa penilaian dianggap sebagai salah satu unsur yang penting dalam meningkatkan kualitas pendidikan.

Secara khusus, penilaian didefinisikan sebagai suatu proses yang sistematis dan mencakup kegiatan mengumpulkan, menginterprestasikan informasi untuk menentukan seberapa jauh seseorang peserta didik atau sekelompok peserta didik mencapai tujuan pembelajaran yang telah ditetapkan, baik aspek pengetahuan, sikap maupun keterampilan (Kusaeri, 2012:8). Penilaian atau evaluasi juga dapat diartikan sebagai proses untuk memberikan atau menentukan nilai kepada objek tertentu berdasarkan suatu kriteria tertentu. Tujuan utama penilaian adalah untuk membuat keputusan dan mengembangkan suatu kebijakan yang bertanggung jawab mengenai pendidikan. Artinya, penilaian atau evaluasi yang dilakukan tidak hanya sekadar mengukur sejauh mana tujuan telah tercapai, tetapi hasil penilaian ini nantinya akan dijadikan sarana untuk pengambilan sebuah keputusan.

Mengingat pentingnya penilaian dalam dunia pendidikan, maka pemerintah mengeluarkan peraturan tentang hal tersebut. Peraturan tersebut termuat dalam UU No. 20 Tahun 2003 pasal 1 ayat 17 dan Peraturan Pemerintah No.19 Tahun 2005 yang menyatakan bahwa lingkup dari Standar Nasional Pendidikan mencakup delapan standar, yaitu: standar isi, standar proses standar kompetensi lulusan, standar pendidik dan tenaga kependidikan, standar sarana dan prasarana, standar pengelolaan, standar pembiayaan, serta standar penilaian pendidikan. Berdasarkan delapan standar tersebut, penilaian pendidikan termasuk komponen yang mendapat perhatian dari pemerintah. Selanjutnya, pemerintah mengeluarkan kembali peraturan terkait penilaian yaitu Peraturan Menteri Pendidikan dan Kebudayaan Republik Indonesia Nomor 4 Tahun 2018 tentang Penilaian Hasil Belajar oleh Satuan Pendidikan dan Penilaian Hasil Belajar oleh Pemerintah menyebutkan bahwa siswa sekolah dasar maupun menengah harus melakukan Ujian Nasional (UN) untuk lulus dan melanjutkan ke jenjang berikutnya. 
Kurikulum menempati posisi sentral dalam pendidikan (Safari, 2018). Dalam hal ini, penilaian harus disesuaikan dengan kurikulum yang berlaku. Tak jarang, pemerintah melakukan perubahan dan penyempurnaan kurikulum. Perubahan kurikulum tersebut dipengaruhi oleh berkembangnya zaman dan teknologi. Penilaian yang terdapat dalam Kurikulum 2013 diharapkan dapat membantu peserta didik untuk meningkatkan kemampuan berpikir tingkat tinggi (Higher Order Thinking Skills/HOTS). Hal tersebut dikarenakan berpikir tingkat tinggi dapat mendorong peserta didik untuk berpikir secara luas dan mendalam tentang materi pelajaran. Kurikulum 2013 juga menekankan pada dimensi pedagogik modern dalam pembelajaran, yaitu menggunakan pendekatan ilmiah. Pendekatan ilmiah (scientific approach) dalam pembelajaran sebagaimana dimaksud meliputi mengamati, menanya, menalar, mencoba, mengkomunikasikan. Siswa dilatih untuk mampu berpikir logis, runtut, dan sistematis dengan menggunakan kapasitas berpikir tinggi.

Penilaian hasil belajar oleh pendidik dilakukan dalam bentuk ulangan, pengamatan, penugasan dan/atau bentuk lain yang diperlukan. Hamalik (2013:168-171) juga mengemukakan bahwa penilaian terhadap hasil belajar dapat dilaksanakan dengan cara tertentu sesuai dengan maksud dan tujuan penilaian, yang dirancang dengan model desain evaluasi, yakni penilaian sumatif, formatif, reflektif, dan kombinasi ketiga model.

Penilaian hasil belajar oleh satuan pendidikan dilakukan dalam bentuk penilaian akhir yaitu Ujian Nasional dan ujian sekolah. Ujian Nasional dapat dikatakan sebagai salah penentu kelulusan seorang peserta didik. Hal tersebut sesuai dengan penelitian Rian \& Almujab (2020) yang mengemukakan bahwa ujian nasional merupakan salah satu instrumen evaluasi dalam pendidikan yang sudah terstandarisasi dan bertujuan untuk mengukur hasil belajar siswa yang dilaksanakan pada akhir pengajaran suatu program pendidikan.

Ujian nasional kerap mendapatkan perhatian yang serius, baik dari kalangan pemerintah, pendidik, maupun peserta didik. Sejalan dengan pendapat Budianingsih, Utama, Sutama (2017) yang mengemukakan bahwa salah satu alat evaluasi yang digunakan pemerintah untuk mengukur keberhasilan pendidikan adalah ujian nasional. Melalui penerapan UN tersebut, pemerintah mengharapkan hasilnya dapat dipergunakan sebagai salah satu pertimbangan untuk pemetaan mutu sekolah, dasar seleksi masuk jenjang pendidikan berikutnya, penentuan kelulusan peserta didik dari sekolah, dan pembinaan dan pemberian bantuan kepada satuan pendidikan untuk meningkatkan mutu pendidikan (Dwiatmoko et al, 2015).

Pembuatan soal Ujian Nasional (UN) harus berpedoman pada peraturan yang berlaku. Peraturan yang dimaksud adalah Surat Keputusan BSNP Nomor 0296/SKEP/BSNP/XI/2018 
tentang Kisi-Kisi Ujian UN untuk Jenjang Dasar dan Menengah. Pembuat soal harus menyesuaikan soal yang dibuat dengan kisi-kisi yang ada. Hal tersebut sesuai dengan Pasal 1 yang menyebutkan bahwa kisi-kisi soal Ujian Nasional adalah acuan dalam pengembangan dan perakitan soal Ujian Nasional yang disusun berdasarkan kriteria pencapaian standar kompetensi lulusan, standar isi, dan kurikulum yang berlaku.

Adapun peningkatan kualitas soal ujian nasional bertujuan untuk memaksimalkan keterampilan berpikir peserta didik. Kesulitan soal ditingkatkan dengan peningkatan banyaknya soal berpikir tingkat tinggi dalam soal Ujian Nasional (UN) (Hasanah, Danaryanti, Suryaningsih, 2019). Berdasarkan penjelasan tersebut, maka tujuan dalam penelitian ini adalah untuk mengetahui dan menganalisis kesesuaian soal Ujian Nasional Bahasa Indonesia pada tingkat SMP tahun ajaran 2018/2019 dalam perspektif kebijakan pendidikan.

\section{METODE}

Penelitian yang dilaksanakan menggunakan metode deskriptif kualitatif yakni penelitian yang bersifat naturalistik dan data yang terkumpul berbentuk kata-kata atau gambar. Penelitian ini dilakukan dengan cara menganalisis soal Ujian Nasional (UN) Bahasa Indonesia pada tingkat SMP tahun ajaran 2018/2019 berdasarkan kisi-kisi Ujian Nasional (UN) yang berlaku.

Pada penelitian ini, yang menjadi instrumen penelitian adalah human instrument atau peneliti itu sendiri. Peneliti melakukan teknik baca dan catat dengan berpedoman pada kisi-kisi analisis butir soal Bahasa Indonesia berdasarkan Surat Keputusan BSNP Nomor 0296/SKEP/BSNP/XI/2018 tentang Kisi-Kisi Ujian UN untuk Jenjang Dasar dan Menengah. Untuk mempermudah perolehan data yang diperlukan, peneliti juga menggunakan bantuan instrumen check-list. Instrumen check-list dilakukan dengan cara memberikan tanda check-list pada tabel yang telah dibuat dan hasilnya digunakan untuk mengetahui ada tidaknya kesesuaian antara butir soal UN yang dibuat dengan kisi-kisi. Peneliti juga menggunakan sistem pengodean dalam proses pengambilan data. Hal tersebut dilakukan untuk mempermudah proses tabulasi data.

Data yang dikumpulkan dalam penelitian ini dengan cara dokumentasi. Dalam penelitian ini, peneliti mencari data dengan mengumpulkan soal Ujian Nasional (UN) Bahasa Indonesia tahun pelajaran 2018/2019. Uji keabsahan data dalam penelitian ini menggunakan uji kredibilitas (credibility). Dalam hal ini, peneliti memberikan data yang telah ditranskripkan untuk dibaca ulang oleh partisipan sehingga dapat menilai kebenaran dari temuan penelitian kualitatif. 


\section{HASIL DAN PEMBAHASAN}

Badan Standar Nasional Pendidikan (BSNP) merilis Ujian Nasional (UN) tahun 2019. Keputusan ini ditetapkan dalam Surat Keputusan BSNP Nomor 0296/SKEP/BSNP/XI/2018 tentang Kisi-Kisi Ujian Nasional (UN). Berdasarkan penelitian yang telah dilakukan, dapat diperoleh hasil dan pembahasan berikut ini.

Tabel 1. Hasil Penelitian

\begin{tabular}{clcc}
\hline No. & \multicolumn{1}{c}{$\begin{array}{c}\text { Lingkup Materi } \\
\text { Berdasarkan Kisi-kisi }\end{array}$} & Jumlah Soal & Persentase \\
\hline 1. & Membaca nonsastra & 12 butir soal & $24 \%$ \\
\hline 2. & Membaca sastra & 14 butir soal & $28 \%$ \\
\hline 3. & Menulis terbatas & 9 butir soal & $18 \%$ \\
\hline 4. & Menyunting kata, kalimat, paragraf & 10 butir soal & $20 \%$ \\
\hline 5. & Menyunting ejaan dan tanda baca & 5 butir soal & $10 \%$ \\
\hline & Total & $\mathbf{5 0}$ butir soal & $\mathbf{1 0 0 \%}$ \\
\hline
\end{tabular}

\section{Ujian Nasional sebagai Evaluasi dalam Sistem Pendidikan}

Evaluasi atau penilaian termasuk dalam salah satu komponen pembelajaran. Mardapi (2005:10) mengemukakan bahwa terkait dengan mutu, maka indikator dari kualitas pendidikan adalah kompetensi lulusan, yaitu kemampuan yang dimiliki lulusan. Kompetensi lulusan dapat berupa kemampuan yang dimiliki lulusan dicirikan dengan pengetahuan, keterampilan dan perilaku yang dapat ditampilkan. Di sisi lain, Rahmawati, Kartikasari, Sukoco (2014) menyatakan bahwa evaluasi dalam bidang pendidikan memiliki tujuan untuk mengetahui perkembangan hasil pembelajaran yang dilakukan oleh peserta didik dan guru. Hasil evaluasi kemudian ditindaklanjuti dalam bentuk program peningkatan kualitas atau mutu pendidikan.

Proses pendidikan selalu memerlukan evaluasi. Setidaknya ada tiga alasan utama mengapa pendidikan memerlukan evaluasi. Pertama, ditinjau dari sudut proses, adanya interdependensi antara ketiga komponen (tujuan pengajaran, materi, dan metode belajar mengajar). Tujuan akan mengarahkan bagaimana pelaksanaan proses belajar-mengajar, (materi, metode belajar mengajar) yang seharusnya dilaksanakan, sekaligus merupakan kerangka acuan untuk melaksanakan evaluasi hasil belajar.

Kedua, ditinjau dari sudut profesionalisme tugas kependidikan, bahwa kegiatan evaluasi hasil belajar merupakan salah satu ciri pendidik profesional. Seorang pendidik profesional selalu menginginkan umpan balik atas proses pembelajaran yang dilakukannya. Hal tersebut 
dilakukan karena mengingat salah satu indikator keberhasilan mengajar salah satunya ditentukan oleh tingkat keberhasilan yang dicapai oleh subjek belajarnya (peserta didik).

Ketiga, secara kelembagaan, kegiatan pendidikan merupakan kegiatan manajemen yang meliputi planning, programming, organizing, actuating, controlling, dan evaluating. Meski secara tegas kegiatan controlling dan evaluating masuk dalam wilayah kajian manajemen, tetapi dalam kegiatan manajemen tradisional terkadang kedua kegiatan tersebut kurang mendapatkan perhatian secara serius, termasuk manajemen pendidikan.

Berdasarkan penjelasan di atas, maka dapat diketahui bahwa dalam proses pendidikan wajib melakukan evaluasi. Evaluasi tersebut dapat dikatakan sebagai upaya untuk mengukur keberhasilan program pendidikan, serta untuk menentukan kualifikasi peserta didik. Selanjutnya, proses evaluasi pendidikan diperlukan untuk menilai keunggulan maupun kelemahan suatu proses pendidikan. Hal tersebut dimaksudkan agar ada perlakuan yang tepat untuk terus meningkatkan mutu pendidikan.

\section{Analisis Soal Ujian Nasional Bahasa Indonesia dalam Perspektif Kebijakan Pendidikan}

Pada prinsipnya, evaluasi merupakan sebuah langkah pertanggungjawaban atas perencanaan program yang telah dilakukan untuk mengukur sejauh mana pencapaian hasil dalam rangka perbaikan pelaksanaan selanjutnya. Evaluasi dalam perspektif alur proses/siklus kebijakan pendidikan, menempati posisi terakhir setelah implementasi kebijakan, sehingga sudah sewajarnya jika kebijakan pendidikan yang telah dibuat dan dilaksanakan lalu dievaluasi. Berdasarkan hasil evaluasi tersebut, maka akan diketahui keberhasilan atau kegagalan sebuah kebijakan. Dengan asumsi, apakah kebijakan dapat dilanjutkan atau perlu perbaikan sebelum dilanjutkan, atau bahkan harus dihentikan.

Berdasarkan Peraturan Menteri Pendidikan dan Kebudayaan Republik Indonesia Nomor 4 Tahun 2018 tentang Penilaian Hasil Belajar oleh Satuan Pendidikan dan Penilaian Hasil Belajar oleh Pemerintah menyebutkan bahwa siswa sekolah dasar maupun menengah harus melakukan Ujian Nasional (UN) untuk lulus dan melanjutkan ke jenjang berikutnya. Oleh karena itu, pembuatan soal Ujian Nasional (UN) harus dipersiapkan dengan matang.

Surat Keputusan BSNP Nomor 0296/SKEP/BSNP/XI/2018 tentang Kisi-Kisi UN untuk jenjang dasar dan menengah dapat dijadikan pedoman untuk pembuatan soal Bahasa Indonesia tingkat SMP untuk jenjang Sekolah Menengah Pertama (SMP). Kisi-kisi soal Ujian Nasional adalah acuan dalam pengembangan dan perakitan soal Ujian Nasional yang disusun berdasarkan kriteria pencapaian standar kompetensi lulusan, standar isi, dan kurikulum yang berlaku. 
Berdasarkan data yang telah diperoleh, soal Ujian Nasional (UN) Bahasa Indonesia tingkat SMP tahun ajaran 2018/2019 terdiri dari 50 butir soal. Butir-butir soal ditulis berdasarkan level kognitif yang memuat pengetahuan dan pemahaman, aplikasi, dan penalaran. Selanjutnya, lingkup materi soal UN Bahasa Indonesia terdiri dari: 1) membaca nonsastra, 2) membaca sastra, 3) menulis terbatas, 4) menyunting kata, kalimat, paragraf, dan 5) menyunting ejaan dan tanda baca.

Berdasarkan soal UN Bahasa Indonesia tingkat SMP tahun ajaran 2018/2019 dapat diperoleh data pemilahan nomor soal berdasarkan lingkup materi sebagai berikut. Pertama, membaca nonsastra. Membaca nonsastra dapat dikatakan sebagai kegiatan untuk menemukan informasi dari sebuah karya sastra, seperti menentukan kalimat utama, gagasan pokok, jenis kata, jenis kalimat, fungsi kata, struktur kalimat, informasi pokok, kata penghubung, dan lain sebagainya.

Pada soal Ujian Nasional (UN) Bahasa Indonesia tingkat SMP tahun ajaran 2018/2019 terdapat 12 soal yang termasuk lingkup materi membaca nonsastra. Soal-soal tersebut yaitu: menentukan makna kata tertentu pada teks (nomor 1), menentukan pernyataan yang sesuai dengan teks (nomor 2), menentukan perbedaan pola penyajian kedua teks laporan (nomor 11), menentukan perbedaan penggunaan bahasa kedua teks laporan (nomor 12), menentukan kalimat utama pada paragraf (nomor 20), menentukan ide pokok paragraf (nomor 21), menentukan ringkasan teks (nomor 22), menentukan simpulan isi paragraf (nomor 23), menentukan kelebihan/kekurangan teks (nomor 24), mengomentari isi teks (nomor 25), menentukan simpulan pendapat pro pada teks (nomor 30), dan menentukan simpulan pendapat kontra pada teks (nomor 31).

Kedua, membaca sastra. Membaca sastra dapat diartikan sebagai proses membaca dan memahami suatu bacaan sastra dengan melihat unsur intrinsik dan ekstrinsiknya seperti dalam puisi, cerpen, novel, drama dan sebagainya.

Pada soal Ujian Nasional (UN) Bahasa Indonesia tingkat SMP tahun ajaran 2018/2019 terdapat 14 soal yang termasuk lingkup materi membaca sastra. Soal-soal tersebut yaitu: menentukan bukti latar tempat/waktu/suasana pada teks (nomor 3), mengomentari isi kutipan cerita (nomor 4), menunjukkan bukti watak tokoh dalam cerpen/fabel (nomor 5), menentukan nilai moral yang terdapat pada kutipan cerita (nomor 6), menentukan makna simbol kata tertentu pada kutipan cerita (nomor 7), menentukan bagian (pengenalan, perumitan, klimaks, peleraian) cerpen (nomor 27), menentukan penyebab konflik cerpen (nomor 28), menetukan akibat konflik cerpen (nomor 29), menentukan tokoh utama pada kutipan cerita (nomor 45), 
menentukan makna kata tertentu pada kutipan cerita (nomor 46), menentukan amanat yang sesuai dengan kutipan cerita (nomor 47), menentukan bukti latar tempat/suasana/waktu pada kutipan cerpen (nomor 48), menentukan pola pengembangan kedua kutipan cerpen (nomor 49), dan menentukan penggunaan bahasa kedua kutipan cerpen (nomor 50).

Ketiga, menulis terbatas. Menulis terbatas dapat diwujudkan dengan melengkapi kalimat atau paragraf dengan istilah atau kata, melengkapi kalimat atau paragraf dengan ungkapan atau peribahasa, melengkapi unsur teks nonsastra, dan melengkapi teks sastra. Pada soal Ujian Nasional (UN) Bahasa Indonesia tingkat SMP tahun ajaran 2018/2019 terdapat 9 soal yang termasuk lingkup materi menulis terbatas. Soal-soal tersebut yaitu: melengkapi teks petunjuk yang rumpang (nomor 8), menyusun urutan teks petunjuk yang diacak (nomor 9), menentukan laporan yang sesuai dengan data (nomor 10), melengkapi kalimat dengan istilah (nomor 13), menentukan variasi kata tertentu pada kalimat (nomor 14), menentukan variasi kalimat lain dari kalimat (nomor 15), menentukan paragraf ulasan sesuai dengan data (nomor 26), melengkapi kalimat dengan kata sifat (nomor 38), dan menyusun urutan teks laporan yang diacak (nomor 42).

Keempat, menyunting kata, kalimat, dan paragraf. Pada soal Ujian Nasional (UN) Bahasa Indonesia tingkat SMP tahun ajaran 2018/2019 terdapat 10 soal yang termasuk lingkup materi menyunting kata, kalimat, dan paragraf. Soal-soal tersebut yaitu: menentukan alasan kesalahan penggunaan kata (nomor 16), menentukan alasan ketidakefektifan kalimat (nomor 17), menentukan alasan ketidakpaduan paragraf (nomor 18), melengkapi kalimat dengan kata bentukan (nomor 19), menunjukkan kata tidak baku pada kalimat (nomor 32), memperbaiki kata bentukan yang tidak baku (nomor 33), melengkapi kalimat dengan konjungsi (nomor 34), memperbaiki kalimat tidak efektif (nomor 35), memperbaiki kalimat yang tidak padu (nomor 36), dan menunjukkan kalimat yang tidak efektif (nomor 43).

Kelima, menyunting ejaan dan tanda baca. Pada soal Ujian Nasional (UN) Bahasa Indonesia tingkat SMP tahun ajaran 2018/2019 terdapat 5 soal yang termasuk lingkup materi menyunting ejaan dan tanda baca. Soal-soal tersebut yaitu: memperbaiki penulisan kata yang tidak tepat (nomor 37), memperbaiki kesalahan penggunaan tanda baca (nomor 39), menggunakan tanda baca pada kalimat (nomor 40), alasan kesalahan penggunaan tanda baca (nomor 41), dan memperbaiki kesalahan penggunaan tanda baca (nomor 44).

Berdasarkan hal tersebut, dapat diketahui bahwa soal Ujian Nasional (UN) Bahasa Indonesia tingkat SMP pada tahun ajaran 2018/2019 sudah memenuhi kriteria kisi-kisi yang sesuai dengan Surat Keputusan BSNP Nomor 0296/SKEP/BSNP/XI/2018. Soal-soal tersebut sudah memenuhi pasal 1 yang menyatakan bahwa kisi-kisi soal Ujian Nasional adalah acuan 
dalam pengembangan dan perakitan soal Ujian Nasional yang disusun berdasarkan kriteria pencapaian standar kompetensi lulusan, standar isi, dan kurikulum yang berlaku. Kemudian, soal UN juga memiliki kesesuaian kebijakan terkait lingkup materi dan tingkat kognitif yang sesuai dengan pasal 2 dan pasal 3. Selanjutnya, soal UN memiliki kesesuaian dengan pasal 4 terkait pengembangan dan perakitan butir soal berdasarkan kisi-kisi soal Ujian Nasional.

\section{SIMPULAN}

Berdasarkan hasil analisis soal Ujian Nasional (UN) Bahasa Indonesia pada tahun ajaran 2018/2019 dapat diketahui bahwa penyusunan soal Ujian Nasional (UN) sudah sesuai dengan Surat Keputusan BSNP Nomor 0296/SKEP/BSNP/XI/2018. Surat keputusan tersebut dijadikan pedoman dalam proses penyusunan soal Ujian Nasional Bahasa Indonesia tingkat SMP. Soal yang disusun berjumlah 50 butir soal dengan bentuk soal pilihan ganda. Soal sudah disusun berdasarkan lingkup materi yang sesuai dengan kurikulum yang berlaku. Lingkup materi tersebut adalah 1) membaca nonsastra, 2) membaca sastra, 3) menulis terbatas, 4) menyunting kata, kalimat, dan paragraf, dan 5) menyunting ejaan dan tanda baca. Jadi, soal Ujian Nasional (UN) Bahasa Indonesia pada tahun ajaran 2018/2019 (UN) sudah sesuai dengan Surat Keputusan BSNP Nomor 0296/SKEP/BSNP/XI/2018, terutama pasal 1, 2, 3, dan 4.

Berdasarkan kesimpulan penelitian, maka dapat dirumuskan saran sebagai berikut. 1) Bagi penelitian selanjutnya, penelitian ini terbatas hanya menganalisis soal Ujian Nasional (UN) Bahasa Indonesia tingkat SMP tahun ajaran 2018/2019 saja, sehingga diharapkan penelitian lainnya perlu dikembangkan dalam cakupan lebih luas dan berbeda. 2) Bagi pembuat soal ujian, hasil penelitian ini dapat dimanfaatkan sebagai pertimbangan dalam membuat soal Ujian Nasional atau soal ujian lainnya sesuai dengan kebijakan yang berlaku. Selanjutnya, pembuat soal dapat lebih memperhatikan sebaran lingkup materi per butir soal, terutama dalam melatih siswa berpikir lebih tinggi. 3) Bagi guru, dapat dijadikan bahan pertimbangan ketika menyusun soal ujian.

\section{REFERENSI}

Budianingsih, R., Utama, I. D. G. B., I Sutama, I. M,. (2017). Validitas dan reliabilitas soal UN Bahasa Indonesia tahun 2016 untuk jurusan IPS. e-Journal Jurusan Pendidikan Bahasa dan Sastra Indonesia Undiksha, 7 (2).

Dwiatmoko, et al. (2015). Analisis statistis data nilai Ujian Nasional dan nilai Sekolah Menengah Atas di Daerah Istimewa Yogyakarta. Jurnal Ilmiah Widya Teknik.

Hamalik, O. (2013). Kurikulum dan Pembelajaran. Jakarta: Bumi Aksara. 
Hasanah, U., Danaryanti, A., Suryaningsih, Y. (2019). Analisis soal Ujian Nasional Matematika SMA tahun pelajaran 2017/2018 ditinjau dari aspek berpikir tingkat tinggi. EDU-MAT: Jurnal Pendidikan Matematika, 7 (1), 51-62.

Kusaeri dan Suprananto. (2012). Pengukuran dan Penilaian Pendidikan. Yogyakarta: Graha Ilmu.

Mardapi, D. (2005). Penyusunan Tes Hasil Relajar. Yogyakarta: Universitas Negeri Yogyakarta.

Mulyasa. (2006). Kurikulum yang Disempurnakan: Pengembangan Standar Kompetensi dan Kompetensi Dasar. Bandung: PT Remaja Rosdakarya.

Rahmawati, L. E., Kartikasari, F., Sukoco, Y. W. T. (2014). Analisis kesalahan berbahasa pada 20 paket soal Ujian Nasional Bahasa Indonesia SMP 2012/2013. Varia Pendidikan, 26 (2).

Riani, D., dan Almujab, S. (2020). Analisis butir soal dan kemampuan siswa dalam menjawab soal ujian nasional pada mata pelajaran ekonomi. Oikos: Jurnal Kajian Pendidikan Ekonomi dan Ilmu Ekonomi, IV (1).

Peraturan Menteri Pendidikan dan Kebudayaan Republik Indonesia Nomor 4 Tahun 2018 tentang Penilaian Hasil Belajar oleh Satuan Pendidikan dan Penilaian Hasil Belajar oleh Pemerintah.

Peraturan Pemerintah No.19 Tahun 2005 tentang Standar Nasional Pendidikan.

Safari. (2018). Kemampuan siswa SMA IPA dan IPS dalam menjawab soal HOTS mata pelajaran Bahasa Indonesia berdasarkan hasil UN 2017. Indonesian Journal of Educational Assessment.

Sanjaya, Wina. (2013). Strategi Pembelajaran Berorientasi Standar Proses Pendidikan. Jakarta: Kencana Prenada Media Group.

Surat Keputusan BSNP Nomor 0296/SKEP/BSNP/XI/2018 untuk Kisi-Kisi UN.

Undang-Undang No. 20 Tahun 2003 tentang Sistem Pendidikan Nasional. 